\title{
PENINGKATAN KEMAMPUAN GURU SDN 006 SENCANO JAYA DALAM MEMBUAT RENCANA PELAKSANAAN PEMBELAJARAN (RPP) BERBASIS INKUIRI
}

\author{
Yusrizal \\ SDN 006 Sencano Jaya, Indragiri Hulu, Indonesia \\ yusrizalspd006@gmail.com \\ Received: August $04^{\text {th }}, 2020$ \\ Revised: August $06^{\text {th }}, 2020$ \\ Accepted: August $10^{\text {th }}, 2020$
}

\begin{abstract}
This research was carried out with the aim of increasing the ability of teachers to make lesson plans (RPP) using inquiry-based learning models, this inquiry-based learning model will have a learning impact on students' positive mental development, because through this learning, students have wide opportunities. to find and find for themselves what he needs, especially in abstract learning. The form of research undertaken was School Action Research (PTS) with 2 cycles. This research was conducted at SDN 006 Sencano Jaya, Batang Peranap District, Indragiri Hulu Regency with a sample size of 9 teachers. Based on the analysis of research data after applying the inquiry learning model, the ability of teachers to make lesson plans, that refer to Permendikbud Number 22 of 2016, has shown an increase, from cycle I to Cycle II. Cycle I to cycle II has increased. In the first cycle the teacher's average score was 71.66, and in the second cycle it increased to 85.00. Likewise, Classical Absorption (DSK) has increased. In the first cycle, the DSK was $35.00 \%$, and in the second cycle it increased to $59.44 \%$. So it can be concluded that this inquiry-based learning model by providing guidance and direction to teachers at SDN 006 Sencano Jaya can be said to be successful because it has increased from cycle I to cycle II.
\end{abstract}

Keyword: inquiry; learning ability; learning implementation plan.

\section{PENDAHULUAN}

Pembelajaran merupakan aktualisasi kurikulum yang menuntut aktivitas, kreatifitas, dan kearifan guru dalam menciptakan dan menumbuhkan kegiatan peserta didik sesuai dengan rencana yang telah diprogramkan secara efektif dan menyenangkan. Keberhasilan suatu pembelajaran di sekolah tidak terlepas dari kompetensi guru dalam dimensi kompetensi guru yang meliputi kompetensi profesional, kompetensi pedagogik, kompetensi kepribadian dan kompetensi sosial. 
Sanjaya (2011) menyatakan bagaimanapun bagus dan idealnya kurikulum pendidikan, bagaimanapun lengkapnya sarana dan prasarana pendidikan, tanpa diimbangi dengan kemampuan guru dalam mengimplementasikannya, maka semuanya akan kurang bermakna.

Dalam hal ini guru harus menguasai prinsip-prinsip dalam pembelajaran yakni pemilihan dan penggunaan pendekatan, strategi pembelajaran, model pembelajaran, metode mengajar, keterampilan menilai hasil belajar, serta memilih dan menggunakan media pembelajaran, sehingga hasil belajar siswa berada pada tingkat yang optimal. Salah satu upaya yang dapat dikembangkan guru adalah dengan memilih dan menerapkan strategi pembelajaran yang memberikan tantangan sekaligus menyenangkan yakni dengan menerapkan pembelajaran yang berbasis inkuiri dalam proses pembelajaran.

Dalam Permendiknas Nomor 41 Tahun 2007 dijelaskan bahwa setiap guru berkewajiban menyusun Rencana Pelaksanaan Pembelajaran (RPP) dengan lengkap dan sistematis agar pembelajaran berlangsung interaktif, inspiratif, menyenangkan, menantang, memotivasi siswa untuk berperan aktif serta memberikan ruang bagi siswa untuk mengembangkan bakat dan minat sesuai dengan perkembangan siswa.

Sebagai seorang guru professional, guru harus memahami dan memiliki kemampuan yang memadai untuk merealisasikan tujuan pendidikan nasional dengan cara memberikan layanan belajar yang bermutu terhadap siswa. Tujuan utama dari penyusunan RPP adalah bagaimana upaya-upaya yang dilakukan guru dalam merencanakan pembelajaran yang lengkap dan sistematis agar terselenggaranya pembelajaran yang berkualitas bagi siswa.

Menurut W.Gulo (2004) berpendapat mengenai strategi pembelajaran inkuiri, Inkuiri yang dalam bahasa Inggris inquiry, berarti pertanyaan, atau pemeriksaan, penyelidikan. Strategi inkuiri berarti suatu rangkaian 17 kegiatan belajar yang melibatkan secara maksimal seluruh kemampuan siswa untuk mencari dan menyelidiki secara sistematis, kritis, logis, analitis, sehingga mereka dapat merumuskan sendiri penemuannya dengan penuh percaya diri. 
Selain itu, Udin S.Winataputra, dkk (2010) mengatakan Inkuiri sebagai suatu cara belajar atau penelaahan sesuatu yang bersifat mencari secara kritis, analitisargumentatif dengan menggunakan langkah-langkah tertentu menuju suatu kesimpulan yang meyakinkan karena didukung oleh fakta, data, atau argumentasi.

Pembelajaran inkuiri ini bertujuan untuk memberikan cara bagi siswa untuk membangun kecakapan-kecakapan intelektual (kecakapan berpikir) terkait dengan proses-proses berpikir reflektif. Jika berpikir menjadi tujuan utama dari pendidikan, maka harus ditemukan cara-cara untuk membantu individu untuk membangun kemampuan itu.

Penelitian ini bertujuan untuk meningkatkan peningkatan kemampuan guru SDN 006 Sencano Jaya dalam membuat Rencana Pelaksanaan Pembelajaran (RPP) berbasis inkuiri.

\section{KAJIAN TEORITIS}

Perangkat pembelajaran memiliki berbagai komponen yang ada didalamnya. Komponen-komponen itu tentunya memiliki pengertian, bentuk, dan format yang berbeda. Trianto (2014) menjelaskan, bahwa terdapat beberapa komponen perangkat pembelajaran, di antaranya berupa silabus dan Rencana Pelaksanaan Pembelajaran (RPP).

RPP merupakan panduan langkah-langkah yang akan dilakukan oleh guru dalam proses pembelajaran yang disusun dalam skenario kegiatan. Perencanaan yang dilakukan diantaranya dengan melakukan pengembangan RPP. Menurut Trianto (2014) menjelaskan bahwa RPP merupakan panduan dan tahap-tahap yang akan dilakukan oleh guru dalam proses pembelajaran yang disusun dalam skenario pembelajaran.

Inkuiri merupakan pembelajaran yang menitikberatkan pada aktifitas dan pemberian pengalaman belajar secara langsung pada siswa. Pembelajaran berbasis inkuiri ini akan membawa dampak belajar bagi perkembangan mental positif siswa, sebab melalui pembelajaran ini, siswa mempunyai kesempatan yang 
luas untuk mencari dan menemukan sendiri apa yang dibutuhkannya terutama dalam pembelajaran yang bersifat abstrak.

Sanjaya (2008) menyatakan bahwa ada beberapa hal yang menjadi ciri utama strategi pembelajaran inkuiri. Pertama, strategi inkuiri menekankan kepada aktivitas siswa secara maksimal untuk mencari dan menemukan, artinya pendekatan inkuiri menempatkan siswa sebagai subjek belajar. Dalam proses pembelajaran, siswa tidak hanya berperan sebagai penerima pelajaran melalui penjelasan guru secara verbal, tetapi mereka berperan untuk menemukan sendiri inti dari materi pelajaran itu sendiri. Kedua, seluruh aktivitas yang dilakukan siswa diarahkan untuk mencari dan menemukan sendiri dari sesuatu yang dipertanyakan, sehingga diharapkan dapat menumbuhkan sikap percaya diri (self belief). Artinya dalam pendekatan inkuiri menempatkan guru bukan sebagai sumber belajar, akan tetapi sebagai fasilitator dan motivator belajar siswa. Aktvitas pembelajaran biasanya dilakukan melalui proses tanya jawab antara guru dan siswa, sehingga kemampuan guru dalam menggunakan teknik bertanya merupakan syarat utama dalam melakukan inkuiri. Ketiga, tujuan dari penggunaan strategi pembelajaran inkuiri adalah mengembangkan kemampuan intelektual sebagai bagian dari proses mental, akibatnya dalam pembelajaran inkuiri siswa tidak hanya dituntut agar menguasai pelajaran, akan tetapi bagaimana mereka dapat menggunakan potensi yang dimilikinya.

Sasaran utama pembelajaran inkuiri, menurut Amri (2010) yang berpendapat bahwa sasaran yang dapat dicapai dengan penerapan inkuiri, meliputi: (1) sasaran sosial, siswa mampu belajar mandiri untuk mengembangkan potensi yang ada di dalam dirinya; (2) sasaran interdisiplin, siswa mampu menerima pengetahuan baru, memahaminya, dan mengaitkannya dengan masalah yang ada di lingkungan sekitarnya; (3) sasaran pemecahan masalah yang merupakan inti dari pembelajaran inkuiri; dan (4) sasaran penerapan, sasaran penerapan konsep harus dikembangkan sendiri oleh siswa dan secara alami siswa bisa menerapkan konsep yang telah diterimanya jika siswa menghadapi suatu masalah. 
Menurut Sanjaya (2008) mengungkapkan bahwa menerapkan model pembelajaran Inkuiri merupakan pendekatan pembelajaran yang berupaya menanamkan dasar-dasar berpikir ilmiah pada diri siswa, sehingga dalam proses pembelajaran ini siswa lebih banyak belajar sendiri, mengembangkan kreativitas dalam memecahkan masalah.

Sanjaya (Juliana, 2018) menyatakan bahwa pembelajaran inkuiri mengikuti langkah-langkah sebagai berikut:

\section{Orientasi}

Pada tahap ini guru melakukan langkah untuk membina suasana atau iklim pembelajaran yang kondusif. Keberhasilan strategi ini sangat tergantung pada kemauan siswa untuk beraktivitas menggunakan kemampuannya dalam memecahkan masalah, tanpa kemauan dan kemampuan itu tak mungkin proses pembelajaran akan berjalan dengan lancar. Hal yang dilakukan dalam tahap orientasi ini yaitu; (1) Menjelaskan topik, tujuan, dan hasil belajar yang diharapkan dapat dicapai oleh siswa, (2) Menjelaskan pokok-pokok kegiatan yang harus dilakukan oleh siswa untuk mencapai tujuan. Pada tahap ini dijelaskan langkahlangkah inkuiri serta tujuan setiap langkah, mulai dari langkah merumuskan merumuskan masalah sampai dengan merumuskan kesimpulan, dan (3) Menjelaskan pentingnya topik dan kegiatan belajar. Hal ini dilakukan dalam rangka memberikan motivasi belajar siswa.

\section{Merumuskan Masalah}

Merumuskan masalah merupakan langkah membawa siswa pada suatu persoalan yang mengandung berbagai alternatif jawaban. Persoalan yang disajikan adalah persoalan yang menantang siswa untuk memecahkan permasalahan tersebut. Pemecahan masalah yang dimaksud tentu saja membutuhkan pemikiran siswa untuk menentukan jawabannya, dan siswa didorong untuk mencari jawaban yang tepat. Proses mencari jawaban itulah yang sangat penting dalam pembelajaran inkuiri terbimbing, oleh karena itu melalui proses tersebut siswa akan memperoleh pengalaman yang sangat berharga sebagai upaya mengembangkan mental melalui proses berpikir. 


\section{Merumuskan Hipotesis}

Hipotesis adalah jawaban sementara dari suatu permasalahan yang dikaji. Sebagai jawaban sementara, hipotesis perlu diuji kebenarannya. Salah satu cara yang dapat dilakukan guru untuk mengembangkan kemampuan menebak (berhipotesis) pada setiap anak adalah dengan mengajukan berbagai pertanyaan yang dapat mendorong siswa untuk dapat merumuskan jawaban sementara atau dapat merumuskan berbagai perkiraan kemungkinan jawaban dari suatu permasalahan yang dikaji.

\section{Mengumpulkan Data}

Mengumpulkan data adalah aktifitas menjaring informasi yang dibutuhkan untuk menguji hipotesis yang diajukan. Dalam pembelajaran inkuiri, mengumpulkan data merupakan proses mental yang sangat penting dalam pengembangan intelektual. Proses pemgumpulan data bukan hanya memerlukan motivasi yang kuat dalam belajar, akan tetapi juga membutuhkan ketekunan dan kemampuan menggunakan potensi berpikirnya.

\section{Menguji Hipotesis}

Menguji hipotesis adalah menentukan jawaban yang dianggap diterima sesuai dengan data atau informasi yang diperoleh berdasarkan pengumpulan data. Menguji hipotesis juga berarti mengembangkan kemampuan berpikir rasional. Artinya, kebenaran jawaban yang diberikan bukan hanya berdasarkan argumentasi, akan tetapi harus didukung oleh data yang ditemukan dan dapat dipertanggung jawabkan.

6. Merumuskan Kesimpulan

Merumuskan kesimpulan adalah proses mendeskripsikan temuan yang diperoleh berdasarkan hasil pengujian hipotesis. Untuk mencapai kesimpulan yang akurat sebaiknya guru mampu menunjukkan pada siswa data mana yang relevan.

Lebih rinci dijelaskan dalam National Risearch Council/NRC (1996) inkuiri merupakan aktivitas multifase yang melibatkan: observasi; mengajukan pertanyaan; mengkaji buku-buku dan sumber informasi lain; merencanakan 
penyelidikan; mereview (menelaah) bukti-bukti yang sudah diketahui; menggunakan alat untuk mengumpulkan, menganalisis, dan menginterpretasi data; mengajukan jawaban-jawaban; menjelaskan dan memprediksi, dan mengkomunikasikan hasil. NRC (1999) menambahkan inkuiri sebagai penggunaan dan pengembangan higher order thinking pada kegiatan kerja ilmiah, oleh karena itu dalam kegiatan inkuiri memerlukan identifikasi terhadap asumsiasumsi, menggunakan berpikir kritis dan logis, dan mempertimbangkan penjelasan alternatif. Inkuiri juga dikatakan merupakan aktivitas eksperimental untuk menguji suatu hipotesis (Joyce, dkk. 2009).

Menurut Beyer (Ayanti, 2020) menyebutkan bahwa pada strategi pembelajaran inkuiri dimana siswa dihadapkan pada persoalan yang harus dipecahkan, mengajukan kemungkinan cara memecahkannya, menguji kemungkinan pemecahannya berdasarkan bukti-bukti, membuat kesimpulan yang dijamin melalui pengujian, dan kemudian menerapkan kesimpulan pada data baru dan menggeneralisasikannya. Selain itu, ditambahkan bahwa seperti cara-cara belajar lainnya, inkuiri mempunyai beberapa komponen yaitu: proses (process), sikap dan nilai (attitudes and value) dan pengetahuan (knowledge).

Berkaitan dengan komponen pengetahuan, Beyer (1971) membagi lagi komponen ini menjadi hakikat pengetahuan (the nature of konwledge) dan alatalat inkuiri (the tools of inquiry). Perlu disadari bahwa pengetahuan tersebut akan selalu berubah, bersifat tentatif, dan perlu diinterpretasikan, sedangkan alat-alat inkuiri dipengaruhi oleh sumber data, analisis konsep dan proses inkuiri secara rasional. Pada komponen sikap dan nilai dari inkuiri ini dikembangkan sikap skeptis, rasa ingin tahu, toleran terhadap ambigu, objektif, kesediaan untuk menangguhkan keputusan (willingness to suspend judgment), respek terhadap bukti-bukti dan respek dalam penggunaan alasan. Untuk komponen proses meliputi lima tahap inkuiri yaitu, (1) mendefinisikan tujuan; (2) mengembangkan jawaban tentatif; (3) menguji jawaban tentatif; (4) membuat kesimpulan; (5) menerapkan kesimpulan pada data baru. 
Penekanan penting bagi guru saat memberikan pola pengajaran inkuiri yaitu bahwa guru bertanggung jawab bagi pembentuk karakter sikap mental siswa sebagai ilmuwan, dan mengarahkan siswa dengan pertanyaan-pertayaan untuk menempatkan mereka benar-benar pada posisi ilmuwan saat melakukan penyelidikan.

Langkah awal untuk mempermudah dan memperlancar jalannya proses belajar mengajar berbasis inkuiri di sekolah adalah perlu adanya contoh Model Rencana Pelaksanaan Pembelajaran (RPP) yang ada disekolah masing-masing dengan menyesuaikan variasi bentuk baru yang tidak terlalu jauh beda dengan RPP yang telah dilaksanakan di sekolah, hanya saja pada tujuan pembelajarannya yang menjabarkan indikator dari kompetensi dasar, sangat perlu menekankan pada keterampilan proses yang diterapkan pada proses pengajarannya.

\section{Kajian Hasil Penelitian Efektivitas Model Inkuiri}

Butts dan Jones (1966) dalam Helgeson (1994) meneliti tentang efektivitas pengajaran inkuiri dalam pengembangan kemampuan pemecahan masalah, hasilnya terbukti bahwa ada hubungan yang signifikan antara pengajaran inkuiri dengan perilaku dan kemampuan memecahkan masalah dengan menggunakan uji TAB Inventory of Science Processes (TISP), namun tidak ada hubungan antara pengajaran inkuiri dengan kemampuan mengingat (recall) pengetahuan faktual sains yang diuji dengan STEP dan Uji Sains Dasar (the Elementary Science Test).

Menurut Davis (Helgeson, 1994) telah meneliti tentang efek penggunaan dua pendekatan pengajaran sains terhadap hasil belajar yaitu: (1) pendekatan ekspositori naskah (expository-text approach) dan (2) pendekatan diskoveri-inkuiri terbimbing (aguided inquiry-discovery approach). Hasil pengajaran sains menunjukkan tiga pengaruh yaitu, (1) pendekatan diskoveri-inkuiri terbimbing secara signifikan lebih efektif daripada pendekatan ekspositori naskah dalam pencapaian pengetahuan dan informasi konten dalam setiap unit pelajaran sains; (2) hasil belajar dalam pemahaman inkuiri dan proses sains sedikit lebih tinggi, 
namun tidak signifikan, untuk kelompok yang diajar dengan pendekatan diskoveriinkuiri terbimbing; (3) siswa yang menerima pengajaran pendekatan diskoveriinkuiri terbimbing menunjukkan secara signifikan sikapnya lebih positif daripada pendekatan ekspositori naskah. Kesimpulannya, tampak bahwa pendekatan diskoveri-inkuiri terbimbing dalam pengajaran menjadi alat bagi penggabungan produk dan proses sains sementara itu juga meningkatkan sikap-sikap positif. lebih tinggi dalam pengetahuan prosedural dan konstruksi pengetahuan logika dan Pembelajaran berorientasi inquiri meningkatkan perkembangan keterampilan mengklasifikasi dan keterampilan mengkomunikasi.

\section{METODE PENELITIAN}

Jenis penelitian adalah penelitian tindakan sekolah (PTS) yang bertujuan untuk mengetahui keberhasilan penerapan metode pemberian tugas untuk meningkatkan kemampuan sekelompok guru dalam memanfaatkan lingkungan sekolah sebagai sumber belajar di SDN 006 Sencano Jaya.

Penelitian ini dilakukan dengan menggunakan empat tahapan, yaitu perencanaan, pelaksanaan, pengamatan dan refleksi yang dilakukan dengan dua siklus. Refleksi ini mengunakan sistem spiral refleksi oleh model Kemmis dan Mc Taggart yang dimodifikasi (Sukidin dkk, 2002) dengan tahapan mulai dari merencanakan pembinaan setiap siklus, pelaksanan pembinaan setiap siklus, observasi pelaksanaan dan refleksi pembinaan setiap siklus, yang dilakukan dari siklus I sampai siklus II dan seterusnya sampai diperoleh rekomendasi kemampuan guru pada siklus terakhir tuntas. Indikator ketuntasan apabila telah mencapai 85 \% subjek daya serapnya $\geq 70$ \% (Depdikbud RI, 1994, dalam Sudjana, 2001 dan Arikunto, 2007).

Secara garis besar, prosedur siklus dilakukan melalui kegiatan perencanaan (plan), siklus (act), observasi (observe) dan refleksi (reflect) (Kemmis dalam Hopkin, 1993, dikutip Sukidin dkk, 2002). 
Subyek penelitian dalam penelitian ini adalah guru di SDN 006 Sencano Jaya. Jumlah guru yang diteliti sebanyak 9 guru. Penelitian dilaksanakan dari tanggal 16 September - 22 Oktober 2019.

Untuk memperoleh data yang diharapkan, maka dalam penelitian ini digunakan tujuh instrumen yaitu, (1) rencana pelaksanaan pembinaan; (2) pedoman observasi aktivitas guru; (3) daftar chek aktivitas guru; (4) instrumen evaluasi guru dalam membuat RPP berbasis inkuiri yang mengacu pada Permendikbud Nomor 22, Tahun 2016; (5) format observasi pembinaan; (6) format diskusi balikan; (7) daftar hadir guru.

Data yang telah diperoleh pada setiap tahapan siklus diolah dan dinalisis melalui enam tahap yaitu, (1) kategori data; (2) interpretasi data; (3) validitas data; (4) pelaksanaan siklus; (5) evaluasi; (6) analisis dan refleksi.

\section{HASIL PENELITIAN DAN PEMBAHASAN}

Berdasarkan hasil observasi terhadap pelaksanaan pembinaan menunjukkan bahwa aspek kemampuan guru dalam membuat RPP berbasis inkuiri, pada siklus I belum mencapai hasil yang baik. Hal ini mengindikasikan bahwa kemampuan guru dalam membuat RPP yang berbasis Inkuiri pada SDN 006 Sencano Jaya masih perlu perencanaan yang lebih baik dengan memperhatikan kelemahan kekuatan yang telah teridentifikasi pada siklus I sebagai dasar perbaikan pada siklus II.

Dengan demikian kegiatan pembinaan pada siklus II telah meningkatkan kemampuan guru dalam membuat RPP berbasis inkuiri, mulai dari membuat RPP untuk setiap siklus, membuat penilaian untuk setiap siklus, membuat angket respon siswa, membuat pedoman observasi aktivitas siswa, membuat daftar check, membuat format observasi aktivitas siswa, membuat format observasi pelaksanaan model pembelajaran oleh guru dan siswa, dan membuat format diskusi balikan.

Peneliti dalam hal ini akan mengamati aktifvitas guru dalam membuat RPP dengan memperhatikan lembar observasi yang ada. yang terjadi tidak hanya dari 
cara hasil pembinaan, tetapi dilihat juga dilihat dari kegiatan pembinaannya, yaitu aktivitas guru. Aktivitas guru dan perolehan skor guru selama pembinaan dari siklus I sampai siklus II telah mengalami perbaikan dan peningkatan.

Kegiatan pembinaan pada siklus II telah memperlihatkan adanya peningkatan aktivitas guru dibanding pada siklus I, mulai dari membuat RPP untuk setiap siklus, membuat penilaian untuk setiap siklus, membuat angket respon siswa, membuat pedoman observasi aktivitas siswa, membuat daftar check, membuat format observasi aktivitas siswa, membuat format observasi pelaksanaan model pembelajaran oleh guru dan siswa, dan membuat format diskusi balikan.

Berdasarkan hasil observasi aktivitas guru selama penelitian dari siklus I sampai siklus II, dapat dilihat pada Tabel 1 dibawah ini:

Tabel 1. Aktivitas Guru Selama Pembinaan dari Siklus I - Siklus II

\begin{tabular}{|c|c|c|c|c|c|c|c|c|c|c|c|c|}
\hline \multirow{3}{*}{$\begin{array}{c}\text { Jumlah } \\
\text { Guru \& } \\
\text { Presenta } \\
\text { se }\end{array}$} & \multicolumn{12}{|c|}{ Aktivitas Guru Selama Pembinaan pada Siklus I - II } \\
\hline & \multicolumn{2}{|c|}{$\begin{array}{c}\text { Terampil } \\
\text { membuat } \\
\text { RPP } \\
\text { berbasis } \\
\text { inkuiri }\end{array}$} & \multicolumn{2}{|c|}{$\begin{array}{c}\text { Terampil } \\
\text { membuat } \\
\text { penilaian } \\
\text { berbasis } \\
\text { inkuiri }\end{array}$} & \multicolumn{2}{|c|}{$\begin{array}{c}\text { Terampil } \\
\text { membuat } \\
\text { angket } \\
\text { respon siswa }\end{array}$} & \multicolumn{2}{|c|}{$\begin{array}{c}\text { Terampil } \\
\text { membuat } \\
\text { pedoman } \\
\text { observasi } \\
\text { aktivitas siswa } \\
\text { berbasis inkuiri }\end{array}$} & \multicolumn{2}{|c|}{$\begin{array}{c}\text { Terampil } \\
\text { membuat } \\
\text { daftar check } \\
\text { berbasis inkuiri }\end{array}$} & \multicolumn{2}{|c|}{$\begin{array}{c}\text { Terampil } \\
\text { membuat format } \\
\text { observasi } \\
\text { aktivitas siswa } \\
\text { berbasis inkuiri }\end{array}$} \\
\hline & I & II & I & II & 1 & II & I & II & I & II & I & II \\
\hline $\begin{array}{c}\text { Jumlah } \\
\text { Guru }\end{array}$ & 7 & 8 & 6 & 8 & 7 & 9 & 5 & 7 & 7 & 8 & 8 & 9 \\
\hline $\begin{array}{c}\text { Presenta } \\
\text { se }\end{array}$ & 77.77 & 83.33 & 75.00 & 83.33 & 77.77 & 91.66 & 69.44 & 77.77 & 77.77 & 83.33 & 83.33 & 91.66 \\
\hline
\end{tabular}

Berdasarkan data dari pada Tabel 1 di atas kemampuan guru dalam membuat RPP berbasis inkuiri dari siklus I sampai siklus II sudah mengalami peningkatan. Pada siklus I guru yang benar terampil dalam membuat RPP berbasis inkuiri berjumlah 7 orang dengan presentase $(77.77 \%)$, dan pada siklus II menjadi 8 orang (83.33\%). Kompetensi guru dalam membuat penilaian berbasis 
inkuiri dengan benar dari siklus I sampai siklus II mengalami peningkatan yaitu pada siklus I guru yang benar-benar terampil berjumlah 6 orang dengan presentase $(75.00 \%)$, dan pada siklus II menjadi 8 orang (83.33\%).

Berdasarkan data pada Tabel 1 di atas kompetensi guru dalam membuat angket respon siswa terhadap penggunaan pembelajaran berbasis inkuiri dengan benar dari siklus I sampai siklus II mengalami peningkatan. Pada siklus I guru yang benar-benar terampil berjumlah 7 orang dengan presentase $(77.77 \%)$, dan pada siklus II menjadi 9 orang (91.66\%). Kemampuan guru dalam terampil membuat pedoman observasi aktivitas siswa dengan benar dari siklus I sampai siklus II mengalami peningkatan. Pada siklus I guru yang benar-benar terampil berjumlah 5 orang dengan presentase (69.44\%), dan pada siklus II menjadi 7 orang $(77.77 \%)$. Berdasarkan data pada Tabel 1 kompetensi guru membuat daftar check dengan benar dari siklus I sampai siklus II mengalami peningkatan. Pada siklus I guru yang benar-benar terampil berjumlah 7 orang $(77.77 \%)$, dan pada siklus II menjadi 8 orang (83.33\%). Berdasarkan data pada Tabel 1 kemampuan guru dalam terampil membuat format observasi aktivitas siswa dengan benar dari siklus I sampai siklus II mengalami peningkatan. Pada siklus I guru yang benarbenar terampil berjumlah 8 orang dengan presentase (83.33\%), dan pada siklus II menjadi 9 orang (91.66\%).

Jumlah Komponen RPP Berbasis Inkuiri yang Dipenuhi oleh Guru (dari total 20 komponen RPP yang sesuai dengan tuntutan Permendikbud No 22 Tahun 2016)

Jumlah komponen RPP berbasis inkuiri yang dipenuhi oleh Guru (dari total 20 komponen RPP yang sesuai dengan tuntutan Permendikbud No 22 Tahun 2016) dapat dilihat pada Tabel 2.

Tabel 2. Skor Guru dari Siklus I - II

\begin{tabular}{|l|l|l|l|}
\hline \multirow{2}{*}{ No } & \multirow{2}{*}{ Kode Guru } & \multicolumn{2}{|c|}{$\%$} \\
\cline { 3 - 4 } & & Siklus I & Siklus II \\
\hline
\end{tabular}




\begin{tabular}{|l|c|l|l|}
\hline 1 & YU & 65,00 & 75,00 \\
\hline 2 & SU & 75,00 & 90,00 \\
\hline 3 & KH & 65,00 & 80,00 \\
\hline 4 & SJ & 70,00 & 85,00 \\
\hline 5 & HE & 60,00 & 75,00 \\
\hline 6 & ST & 85,00 & 95,00 \\
\hline 7 & WW & 75,00 & 90,00 \\
\hline 8 & NA & 70,00 & 85,00 \\
\hline 9 & FM & $\mathbf{7 1 , 6 6}$ & 90,00 \\
\hline & Rata-rata & $\mathbf{3 5 , 0 0}$ & $\mathbf{8 5 , 0 0}$ \\
\hline & DSK & & $\mathbf{5 9 , 4 4}$ \\
\hline
\end{tabular}

Berdasarkan data pada Tabel 2 di atas, diperoleh data pada Siklus I, skor tertinggi adalah 85,00, sedangkan yang terendah 60,00 dan rata-ratanya adalah 71,66 serta jumlah guru yang mengalami ketuntasan belajarnya sebanyak 4 orang (35.00\%). Pada Siklus II, nilai rata-rata harian tertinggi adalah 95,00, sedangkan yang terendah 75,00 dan rata-ratanya adalah 85,00 , dengan jumlah guru yang mengalami ketuntasan belajarnya sebanyak 9 guru (59.44.\%).

Berdasarkan data pada Tabel 2, menunjukkan rata-rata dan daya serap klasikal jumlah komponen RPP berbasis inkuiri yang dipenuhi oleh guru (dari total 20 komponen RPP yang sesuai dengan tuntutan Permendikbud No. 22 Tahun 2016) dari siklus I sampai pada siklus II mengalami peningkatan. Pada siklus I skor rata-rata guru yaitu 71,66, dan pada siklus II meningkat menjadi 85,00. Begitu juga dengan Daya Serap Klasikal (DSK) mengalami peningkatan. Pada siklus I DSK sebesar 35.00\%, dan pada siklus II meningkat menjadi 59.44\%.

Dapat disimpulkan dari hasil diatas bahwa kegiatan pembinaan aktivitas guru dari siklus I dan Siklus II, bahwa guru semakin aktif pada setiap sesi dan tiap indikator yang dilakukan. semua guru berperan aktif mulai dari membuat RPP untuk setiap siklus, membuat penilaian untuk setiap siklus, membuat angket respon siswa, membuat pedoman observasi aktivitas siswa, membuat daftar 
check, dan membuat format observasi aktivitas siswa. Walaupun pada awalnya banyak yang belum terampil tetapi pada siklus II sudah menunjukkan kemajuan yang sangat pesat.

\section{SIMPULAN DAN REKOMENDASI}

Berdasarkan uraian yang telah dipaparkan di atas, maka peneliti membuat kesimpulan dari hasil penelitian yang dilakukan terhadap guru di SDN 006 Sencano Jaya yaitu pada kegiatan pembinaan guru SDN 006 Sencano Jaya bahwa aktivitas guru dalam membuat RPP berbasis inkuiri, membuat penilaian, membuat angket respon siswa, membuat pedoman observasi aktivitas siswa, membuat daftar check, membuat format observasi aktivitas siswa, membuat format observasi pelaksanaan model pembelajaran oleh guru dan siswa, dan membuat format diskusi balikan belum memuaskan, sehingga perlu adanya perbaikan dari siklus I menjadi siklus II.

Kegiatan pembinaan pada siklus II, menunjukkan bahwa aktivitas guru mulai dari membuat RPP berbasis inkuiri, membuat penilaian, membuat angket respon siswa, membuat pedoman observasi aktivitas siswa, membuat daftar check, membuat format observasi aktivitas siswa, membuat format observasi pelaksanaan model pembelajaran oleh guru dan siswa, dan membuat format diskusi balikan sudah meningkat dan lebih baik dibanding siklus I. Siklus II ini mengakhiri penelitian tindakan sekolah, kegiatan pembinaan pada guru melalui observasi-refleksi-rekomendasi, studi dokumentasi angket, workshop, dan FGD.

Selama melakukan pembinaan terhadap guru terhadap peningkatan kemampuan dalam membuat rencana pelaksanaan pembelajaran (RPP) dalam model pembelajaran berbasis inkuiri, peneliti berusaha melaksanakan bimbingan serta arahan secara adil dan menyeluruh pada setiap kelompok guru yang ada di SDN 006 Sencano Jaya, supaya setiap guru berpartisipasi dalam setiap tahapnya secara aktif. 
Berdasarkan kesimpulan di atas, maka peneliti memberikan saran sebagai berikut: (1) untuk penyelenggaraan supervisi, penyelenggaraan supervisi harus dilaksanakan dengan sebaik mungkin agar guru dapat meningkatkan kemampuan dan keterampilan guru dalam membuat RPP berbasis inkuiri; (2) bagi peneliti lain, penelitian ini bisa dijadikan acuan dalam penelitian selanjutnya dalam cakupan sekolah yang lebih luas; dan (3) bagi pendidikan, penelitian ini bisa menjadi referensi ilmu pengetahuan.

\section{DAFTAR PUSTAKA}

Amri, S., dkk. (2010). Proses Pembelajaran Kreatif dan Inovatif dalam Kelas. Jakarta: Prestasi Pustakarya.

Arikunto, S. (2007). Dasar-Dasar Evaluasi Pendidikan. Jakarta: Bumi Aksara

Aryanti. (2020). Peningkatan Kemampuan Guru SMA Kartika XIX 2 Bandung Membuat Rencana Pelaksanaan Pembelajaran (RPP) Berbasis Inkuiri Yang Mengacu Permendikbud No. 22 Tahun 2016. Jurnal PAJAR (Pendidikan dan Pengajaran). Vol 4 (3), 489-498. ISSN Online : 2614 -1337

Beyer, B.K. (1971). Inquiry in the Social Studies Classroom. A Strategy for Teaching. Columbus Ohio: Charles E. Merill Publishing Company.

Gulo, W. (2002). Strategi Belajar Mengajar. Jakarta: PT. Gramedia Widiasarana Indonesia

Helgeson, S.L. (1994). Research on Problem Solving; Middle School. In: Gabel, D.L. (ed). Handbook of Research on Science Teaching and Learning. A Project of the NSTA. New York: Macmillan Publishing Company.

Joyce, B., dkk. (2009). Models of Teaching. Eighth ed. Boston: Allyn and Bacon.

Juliana, S. (2018). Penerapan Model Pembelajaran Inkuiri Terbimbing Untuk Meningkatkan Hasil Belajar IPA Siswa Kelas VIII semester II SMPN 5 Siak Kecil Kecamatan Siak Kecil Kabupaten Bengkalis. Jurnal PAJAR (Pendidikan dan Pengajaran). Vol 2 (4), 531-539. ISSN Online: 2614 - 1337

National Research Council. (1996). National Science Education Standard. Washington D.C.: National Academi Press.

NSTA \& AET. (2003). Standard for Science Teacher Preparation, New York: Gerland Science. Taylor \& Francis Group.

Permendiknas Nomor 16 Tahun 2007 tentang Standar Kualifikasi Akademik dan Kompetensi Guru.

Permendiknas Nomor 41 Tahun 2007 tentang Standar Proses.

Salpeter. (2001). Century skill: Have Student Ready. [Online]. Tersedia: http://www.21stCenturyskill.org. [19 September 2008] 
Sanjaya, W. (2008). Strategi Pembelajaran Berorientasi Standar Proses Pendidikan. Jakarta: Kencana Prenada Media Group.

Sanjaya, W. (2011). Strategi Pembelajaran Berorientasi Standar Proses Pendidikan. Jakarta: Kencana Prenada Media.

Sudjana, N. (2001). Dasar-Dasar Proses Belajar Mengajar. Bandung: Sinar Baru Algesindo.

Sukidin, dkk. (2002). Penelitian Tindakan Kelas. Laporan Penelitian. IKIP Bandung tidak diterbitkan.

Syah, M. (2004). Psikologi Belajar. Bandung: Remaja Rosda Karya

Tan, O. S. (2003) Problem based learning Innovation: Using Problems to Power Learning in the 21st century. Singapore: Thomson Learning.

Trianto, I. B. (2014). Mendesain Model Pembelajaran Inovatif, Progresif dan Kontekstual. Jakarta: Prenadamedia Group.

Wijayana, A., \& Yunita D. (2017). Pengaruh Media Video Pembelajaran Terhadap Hasil Belajar IPA Ditinjau dari Keaktifan Siswa. Jurnal Sosiohumaniora, 3 ( 2).

Winataputra, U. S., dkk. (2010). Materi dan Pembelajaran IPS SD. Jakarta: Universitas Terbuka 